\title{
Efek Pemanasan Biosolar B30 Terhadap Kinerja Dan Pembakaran pada Mesin Diesel Type TV-1
}

\author{
Andi Erwin Eka Putra ${ }^{1 *}$ \\ ${ }^{1}$ Laboratorium Motor Bakar, Departemen Teknik Mesin, Universitas Hasanuddin, Gowa 92171, Indonesia \\ *erwinep@eng.unhas.ac.id
}

\begin{abstract}
This study aims to analyze the performance and combustion of preheating bio-diesel B30. The calorific value of bio-diesel B30 distributed by Pertamina was tested with a bomb calorimeter. Bio-diesel B30 flows into the combustion chamber through a heat exchanger to $60^{\circ} \mathrm{C}$ of B30 temperature. The diesel engine type is TV-1 type (vertical type) with specifications of 1 cylinder, 4 stroke, $661 \mathrm{cc}$, power of $3.5 \mathrm{~kW}$ at $1500 \mathrm{rpm}$, and compression ratio of 12:1 to 18:1. Tests were carried out at compression ratios of 14:1, 16:1, 18:1 at braking loads of 3 and $9 \mathrm{~kg}$ by comparing biodiesel without and with heating at $60^{\circ} \mathrm{C}$. The results obtained show that B30 with $60{ }^{\circ} \mathrm{C}$ causes lower SFC and indication power, and higher mechanical efficiency. The combustion characteristics of $B 30$ with $60^{\circ} \mathrm{C}$ show a slower SoC and a shorter combustion process, and a decreased heat release value.
\end{abstract}

Keywords: B30; combustion performance, compression ratio, cylinder pressure; heat release

\begin{abstract}
Abstrak: Penelitian ini bertujuan untuk menganalisis kinerja mesin diesel dan pembakaran dari biosolar B30 yang dipanaskan sebelum diinjeksi ke dalam ruang bakar. Biosolar B30 yang dipasarkan oleh Pertamina sebelumnya diuji nilai kalor dengan bomb calorimeter. Biosolar B30 dialirkan ke ruang bakar dengan melewati tangki pemanas sampai temperatur biosolar mencapai $60{ }^{\circ} \mathrm{C}$. Mesin diesel yang digunakan adalah type TV-1 (tipe vertikal) dengan spesifikasi mesin 1 silinder, 4 langkah, kapasitas $661 \mathrm{cc}$, Daya 3,5 kW pada $1500 \mathrm{rpm}$, dan rasio kompresi mesin 12:1 sampai 18:1. Pengujian dilakukan pada rasio kompresi 14:1, 16:1, dan 18:1 pada beban $3 \mathrm{~kg}$ dan $9 \mathrm{~kg}$ dengan membandingkan biosolar tanpa pemanasan dan dengan pemanasan $60^{\circ} \mathrm{C}$. Hasil yang diperoleh memperlihatkan bahwa biosolar B30 dengan pemanasan $60{ }^{\circ} \mathrm{C}$ menyebabkan SFC dan daya indikasi lebih rendah serta efisiensi mekanik yang lebih tinggi. Karakteristik pembakaran biosolar B30 dengan pemanasan $60{ }^{\circ} \mathrm{C}$ memperlihatkan $\mathrm{SoC}$ yang lambat dan proses pembakaran yang berlangsung lebih singkat, serta tekanan maksimum yang lebih tinggi dan nilai pelepasan panas yang menurun.
\end{abstract}

Kata kunci : B30; Kinerja pembakaran; Rasio kompresi, tekanan silinder, pelepasan panas

\section{PENDAHULUAN}

Peningkatan efisiensi teknologi di bidang otomotif menyebabkan bahan bakar minyak (BBM) masih mendominasi dalam konsumsi energi total dengan laju pertumbuhan rata-rata sebesar 3,5\% per tahun [1]. BBM berupa bensin dan minyak solar hampir seluruhnya digunakan dalam bidang otomotif ini berasal dari minyak bumi sehingga cadangan minyak fosil menjadi menurun. Salah satu usaha telah dilakukan untuk mengurangi ketergantungan BBM adalah melakukan substitusi dengan bahan bakar nabati dan hewani. Biodiesel merupakan salah satu minyak nabati dan hewani yang telah dimanfaatkan sebagai subtitusi minyak solar karena mempunyai sifat-sifat yang similar dengan minyak solar dan disusun dari ester monoalkil dari asam lemak rantai panjang [2]. Bahan baku utama biodiesel di Indonesia adalah minyak sawit (crude palm oil, CPO) [3] dimana produksi CPO tahun 2019 mencapai 48.42 juta ton [4].

Penggunaan langsung CPO sebagai bahan bakar akan mengurangi kinerja mesin disebabkan massa molekul yang besar, volatilitas rendah, viskositas kinematis tinggi sehingga dapat menyebabkan penebalan dan pembentukan gel, serta lengketnya minyak. Oleh karena itu, CPO perlu diolah lebih lanjut melalui metode seperti metode pencampuran dengan minyak diesel, metode mikroemulsifikasi, metode pirolisis, dan metode transesterifikasi [5]. Biodiesel yang dihasilkan dari metode-metode tersebut harus memenuhi standar dan mutu (spesifikasi) yang ditetapkan dalam keputusan direktur jenderal energi baru, terbarukan dan konservasi energi untuk dapat digunakan sebagai campuran minyak solar yang dipasarkan di dalam negeri [6]. Tata niaga campuran $70 \%$ minyak solar dengan 
$30 \%$ biodiesel yang dikenal sebagai biosolar B30 telah dilakukan sejak 2020 berdasarkan peraturan Menteri ESDM no. 32 tahun 2015 [7].

Pencampuran CPO dan minyak diesel dengan rasio volume campuran $95: 5,90: 10,85: 15$ telah digunakan pada mesin diesel 1 silinder, 4 langkah, volume $547 \mathrm{cc}$ dengan daya maksimum $7.5 \mathrm{~kW}$, maksimum torsi $3.6 \mathrm{~kg}-\mathrm{m}$ pada $1600 \mathrm{rpm}$. Sifat-sifat pencampuran $95: 5$ mendekati sifat-sifat minyak diesel. Sedangkan torsi dan daya mesin menurun sebesar $5-17 \%$ saat menggunakan campuran tersebut. Konsumsi bahan bakar spesifik (Spesific fuel consumption, SFC) dari campuran bahan bakar ini lebih besar 7 - 33\% dari minyak diesel [8]. Selain itu, karakteristik pembakaran dari variasi campuran biodiesel (B10, B20, B40) telah diinjeksikan ke dalam sistem burner dengan nosel bervariasi $(1.25,1.50,1.75)$. Temperatur dinding diinvestigasi pada setiap komposisi biodiesel dengan variasi nosel yang memperlihatkan bahwa temperatur dinding cenderung lebih rendah dibanding minyak diesel dengan temperatur dinding B40 yang paling rendah [9].

Karakteristik kinerja mesin dan proses pembakaran sangat dipengaruhi oleh densitas dan viskositas biodiesel. Sedangkan, densitas dan viskositas campuran biodiesel sedikit lebih tinggi dibandingkan dengan minyak solar menjadi hambatan yang signifikan dalam komersialisasi [10]. Oleh karena itu, beberapa penelitian untuk menurunkan densitas dan viskositas campuran biodiesel telah diinvestigasi. Campuran CPO dan minyak solar dengan 25\%, 50\%, dan 75\% dipanaskan pada suhu $60{ }^{\circ} \mathrm{C}$ pada putaran mesin $1000 \mathrm{rpm}$ - $3000 \mathrm{rpm}$ dengan pembukaan throttle konstan menghasilkan torsi dan daya yang lebih tinggi pada putaran di bawah 2000 rpm. Selain itu, Konsumsi bahan bakar spesifik pengereman (brake specific fuel consumption, BSFC) lebih tinggi dibandingkan minyak diesel pada putaran mesin yang sama dan meningkat pada putaran mesin lebih dari $2000 \mathrm{rpm}$ [11]. Selain itu, Lim (2002) telah melakukan variasi pemanasan $\mathrm{CPO}$ dari $60{ }^{\circ} \mathrm{C}$ sampai dengan $100{ }^{\circ} \mathrm{C}$. Hasilnya memperlihatkan bahwa kinerja mesin dan karakteristik pembakaran optimum pada temperatur pemanasan $\mathrm{CPO} 60^{\circ} \mathrm{C}[\mathbf{1 2}]$.

Berdasarkan uraian di atas maka penelitian ini bertujuan untuk menganalisis kinerja mesin diesel dan pembakaran dari biosolar B30 yang dipanaskan sebelum diinjeksi ke dalam ruang bakar.

\section{METODE PENELITIAN}

Bahan bakar yang digunakan pada penelitian ini adalah biosolar B30 yang dipasarkan melalui stasiun pengisian bahan bakar umum (SPBU) milik Pertamina yang ada di sekitar Kampus Fakultas Teknik Universitas Hasanuddin di Gowa. Nilai kalor biosolar B30 ini diuji menggunakan bomb calorimeter. Biosolar yang telah dimasukkan dalam tangki penampungan bahan bakar mesin ini. Pada saat mesin dinyalakan, biosolar dialirkan ke ruang bakar dengan melewati tangki pemanas sampai temperatur biosolar mencapai $60{ }^{\circ} \mathrm{C}$.

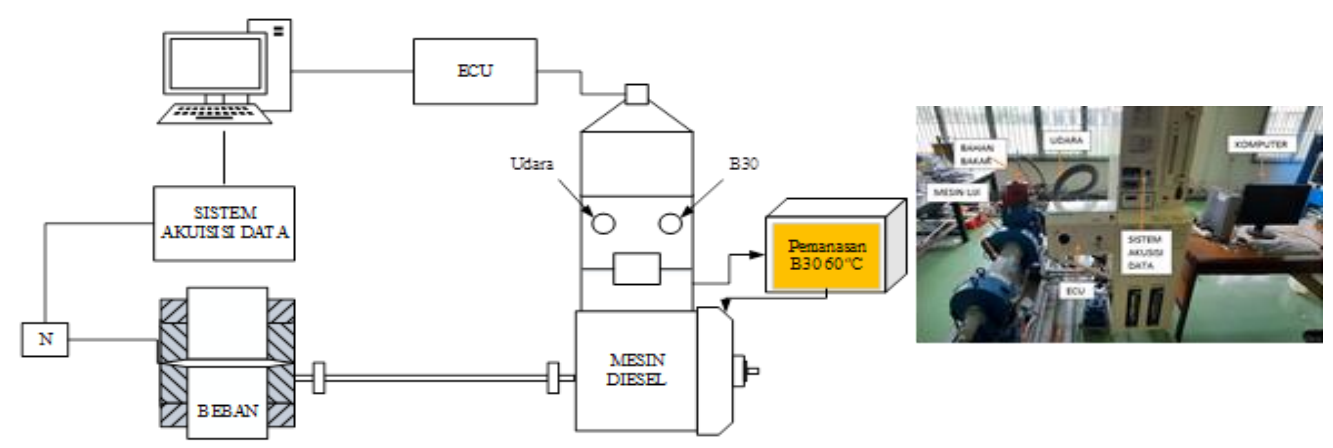

Gambar 1. Mesin Penelitian 
130 Andi Erwin Eka Putra. Efek Pemanasan Biosolar B30 Terhadap Kinerja Dan Pembakaran pada Mesin Diesel Type TV-1

Mesin diesel yang digunakan adalah type TV-1 (tipe vertikal) dengan spesifikasi mesin 1 silinder, 4 langkah, berpendingin air, Panjang langkah $110 \mathrm{~mm}$, diameter silinder 87,5 mm. Kapasitas $661 \mathrm{cc}$, Daya 3,5 kW pada $1500 \mathrm{rpm}$, rasio kompresi mesin 12 : 1 sampai 18 : 1, seperti yang diperlihatkan pada gambar 1 .

\section{HASIL DAN PEMBAHASAN}

Nilai kalor biosolar B30 diperoleh sebesar $34.230 \mathrm{~kJ} / \mathrm{kg}$. Densitas diuji pada temperatur $40{ }^{\circ} \mathrm{C}$ sebesar $863 \mathrm{~kg} / \mathrm{m}^{3}$ (ASTM D4052). Setelah sifat-sifat tersebut diketahui selanjutnya dilakukan pengujian kinerja mesin dan pembakaran pada variasi rasio kompresi 14:1, 16:1 dan 18:1 dan beban pengereman 3 dan $9 \mathrm{~kg}$ untuk biosolar B30 tanpa pemanasan dan biosolar B30 dengan pemanasan 60 ${ }^{\circ} \mathrm{C}$. Pada gambar 2, daya efektif mesin dengan biosolar B30 tanpa pemanasan dan pemanasan $60{ }^{\circ} \mathrm{C}$ cenderung konstan pada perubahan rasio kompresi pada kisaran $0.84-0.91 \mathrm{~kW}$ tergantung pada fluktuasi putaran mesin yang terjadi. Sedangkan perubahan beban dari $3 \mathrm{~kg} \mathrm{ke} 9 \mathrm{~kg}$, daya efektif cenderung meningkat pada kisaran $2,4-2,5 \mathrm{~kW}$ akibat meningkatnya nilai torsi mesin. Sedangkan konsumsi bahan bakar spesifik (SFC) untuk biosolar dengan pemanasan $60{ }^{\circ} \mathrm{C}$ cenderung lebih rendah dibandingkan dengan biosolar tanpa pemanasan. Peningkatan temperatur bahan bakar akan meningkatkan kandungan energi sehingga SFC yang rendah lebih diinginkan [13].

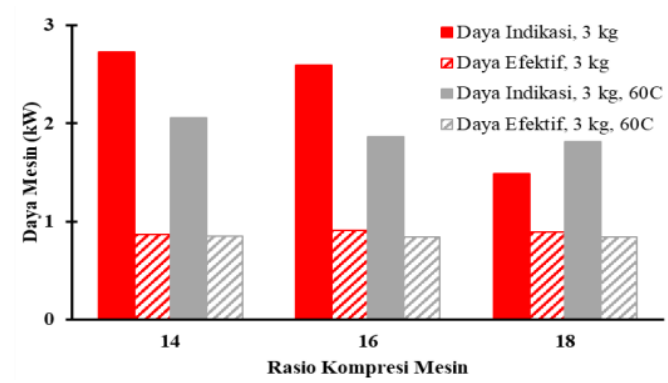

a

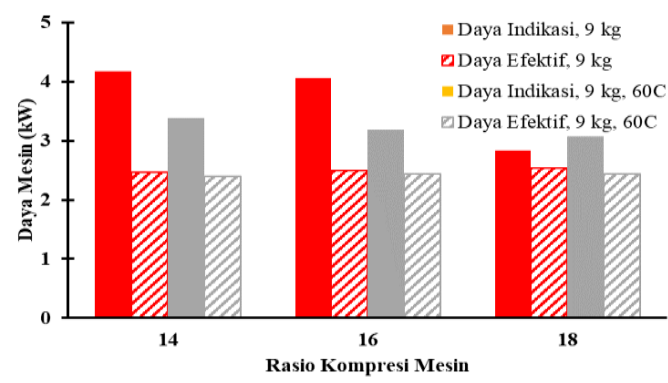

b

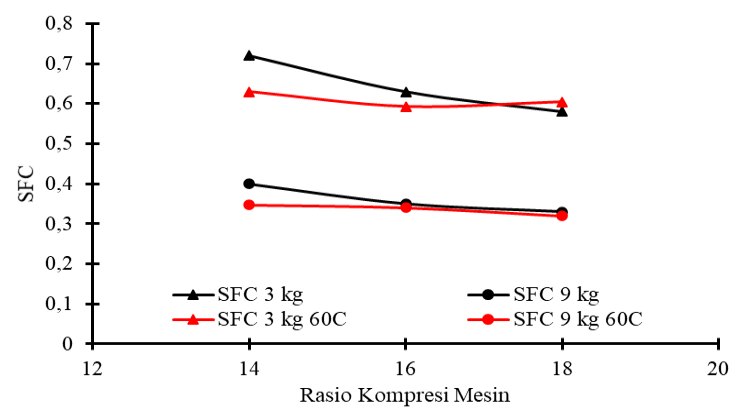

(c

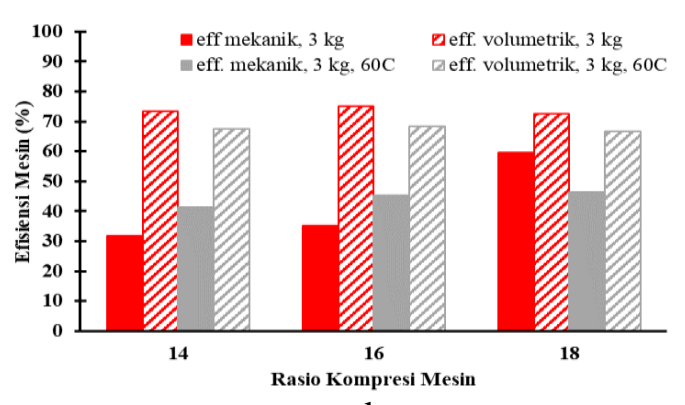

d

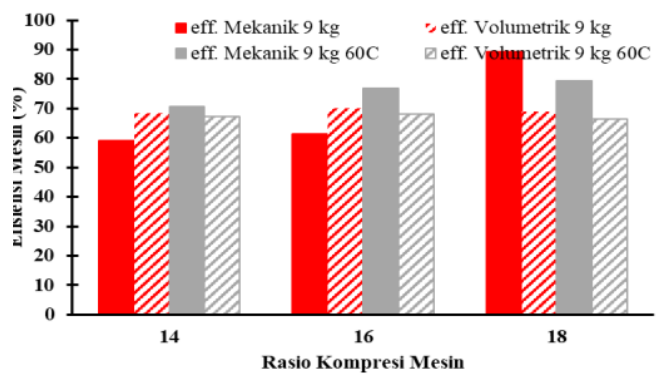

e 
Gambar 2. Kinerja Mesin dengan bahan bakar biosolar tanpa pemanasan dan pemanasan $60^{\circ} \mathrm{C}$. Daya mesin pada beban $3 \mathrm{~kg}$ (a) dan beban $9 \mathrm{~kg}$ (b), SFC (c), efisiensi mesin pada beban $3 \mathrm{~kg}$ (d) dan beban $9 \mathrm{~kg}$ (e).

Daya indikasi mesin dengan bahan bakar biosolar dengan pemanasan $60{ }^{\circ} \mathrm{C}$ memperlihatkan nilai yang lebih rendah pada rasio kompresi 14:1 dan 16:1 dibandingkan dengan biosolar tanpa pemanasan, dan sebaliknya pada rasio kompresi 18:1, daya indikasi biosolar tanpa pemanasan lebih tinggi. Hal yang sama pada perubahan rasio kompresi dari 14:1 ke 18:1 dimana daya indikasi cenderung menurun pada beban yang sama. Penurunan daya indikasi ini dikarenakan bahan bakar yang dipanasi akan lebih cepat mencapai kondisi penyalaan awal seperti terlihat pada gambar 3, sehingga periode persiapan pembakaran akan semakin singkat yang berdampak pada daya indikasi menurun. Gambar 2 juga memperlihatkan bahwa daya indikasi yang diubah menjadi daya efektif cenderung lebih besar pada bahan bakar dengan pemanasan $60{ }^{\circ} \mathrm{C}$. Demikian juga dengan efisiensi mekanik mesin diesel dengan biodiesel $\mathrm{B} 30$ dengan pemanasan $60{ }^{\circ} \mathrm{C}$ cenderung lebih tinggi dibandingkan dengan biodiesel B30 tanpa pemanasan. Sebaliknya, Efisiensi volumetrik cenderung lebih rendah pada biodiesel B30 dengan pemanasan $60{ }^{\circ} \mathrm{C}$ pada beban $3 \mathrm{~kg}$ dan cenderung sama pada beban $9 \mathrm{~kg}$.
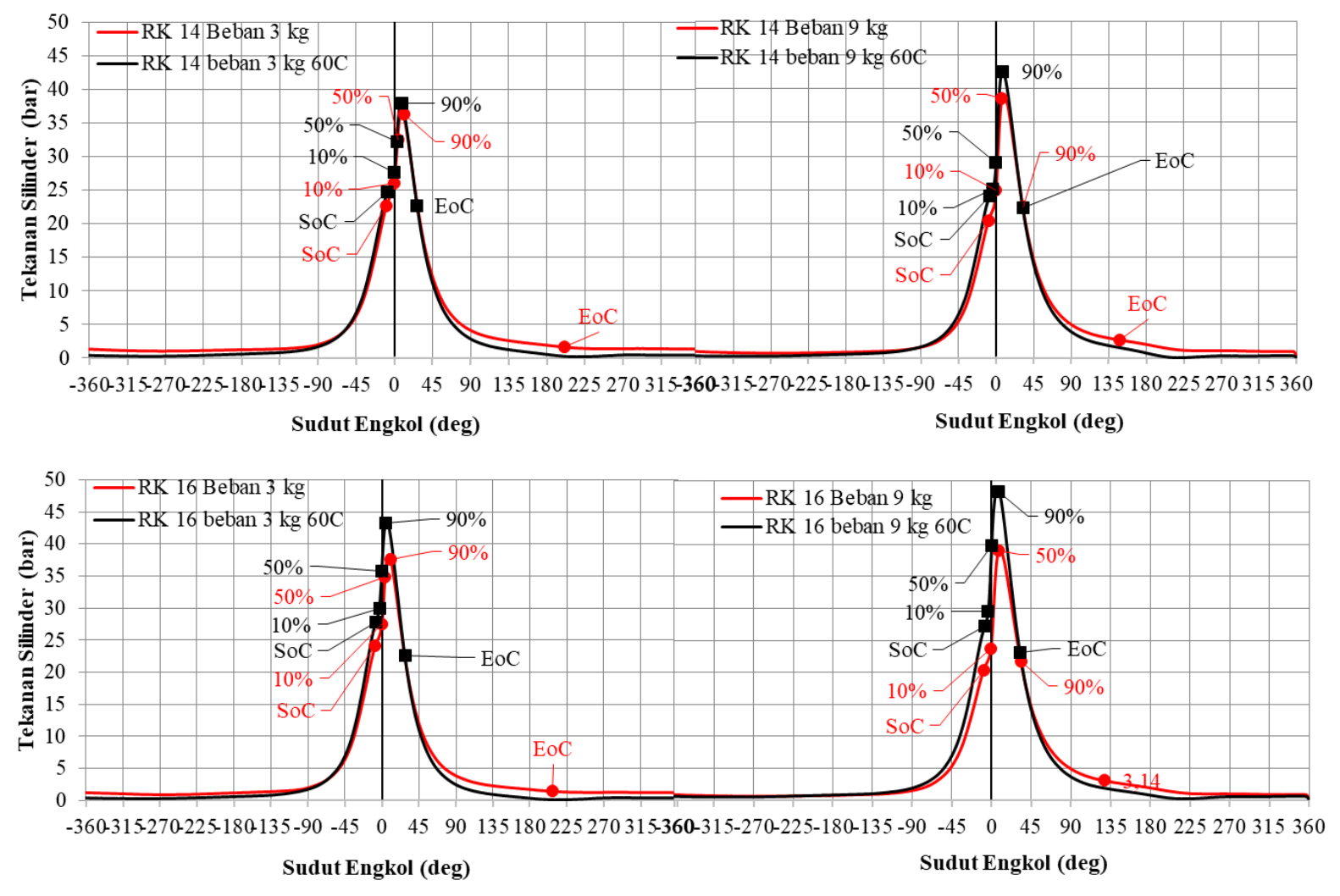
132 Andi Erwin Eka Putra. Efek Pemanasan Biosolar B30 Terhadap Kinerja Dan Pembakaran pada Mesin Diesel Type TV-1

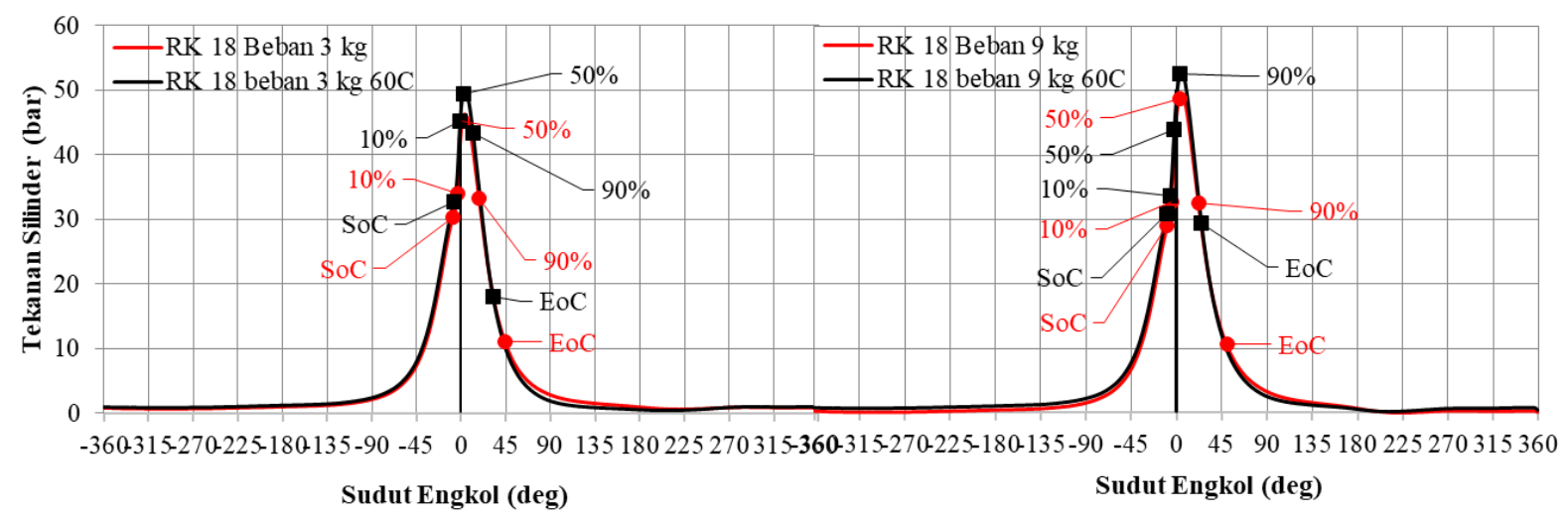

Gambar 3. Tekanan Pembakaran dalam silinder mesin

Tahapan pembakaran untuk bahan bakar biosolar B30 tanpa pemanasan dan pemanasan $60{ }^{\circ} \mathrm{C}$ pada beban 3 dan $9 \mathrm{~kg}$, variasi rasio kompresi pada 14:1, 16:1, dan 18:1 diperlihatkan pada gambar 3 . Perubahan jarak antara SOC (start of combustion) ke 10\%, dimana kondisi ini disebut ignition delay atau proses keterlambatan pembakaran yang merupakan awal pembakaran. Dimana proses ini terjadi saat bahan bakar mulai disemprotkan oleh nozle sampai mulai terbakar. Dimana semakin pendek jarak ignition delay maka semakin bagus pembakarannya dan sebaliknya jika semakin panjang ignition delay maka semakin buruk pembakarannya. Jarak antara 10\% sampai titik 50\% disebut pembakaran cepat atau tak terkendali. Pada tahap ini tekanan naik dengan cepat, karena selama periode keterlambatan pembakaran bahan bakar telah mempunyai waktu untuk menyebar dan mendapat udara di sekitarnya. Dari 50\% sampai titik $90 \%$ disebut pembakaran terkendali, pada akhir tahap kedua tekanan dan temperatur sangat tinggi sehingga bahan bakar langsung terbakar ketika masuk ruang bakar dan kenaikan tekanan selanjutnya dapat dikendalikan dengan cara mekanik murni dengan laju penginjeksian. Dari $90 \%$ sampai EOC (end of combustion) disebut after burning atau pembakaran lanjutan dimana pada fase ini terjadi pembakaran bahan bakar yang belum terbakar. Bahan bakar biosolar dengan pemanasan $60{ }^{\circ} \mathrm{C}$ cendrung lebih lambat SoCnya dan sedangkan, akhir pembakaran (End of Combustion, EoC) berlangsung lebih singkat dibandingkan biosolar B30 tanpa pemanasan seperti diperlihatkan pada gambar 3.
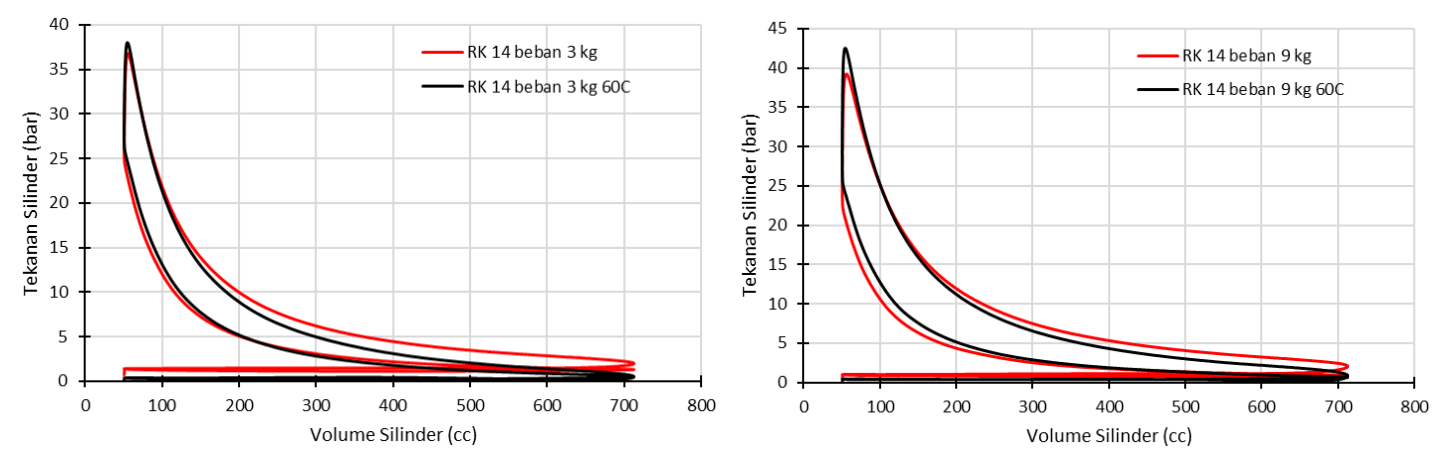

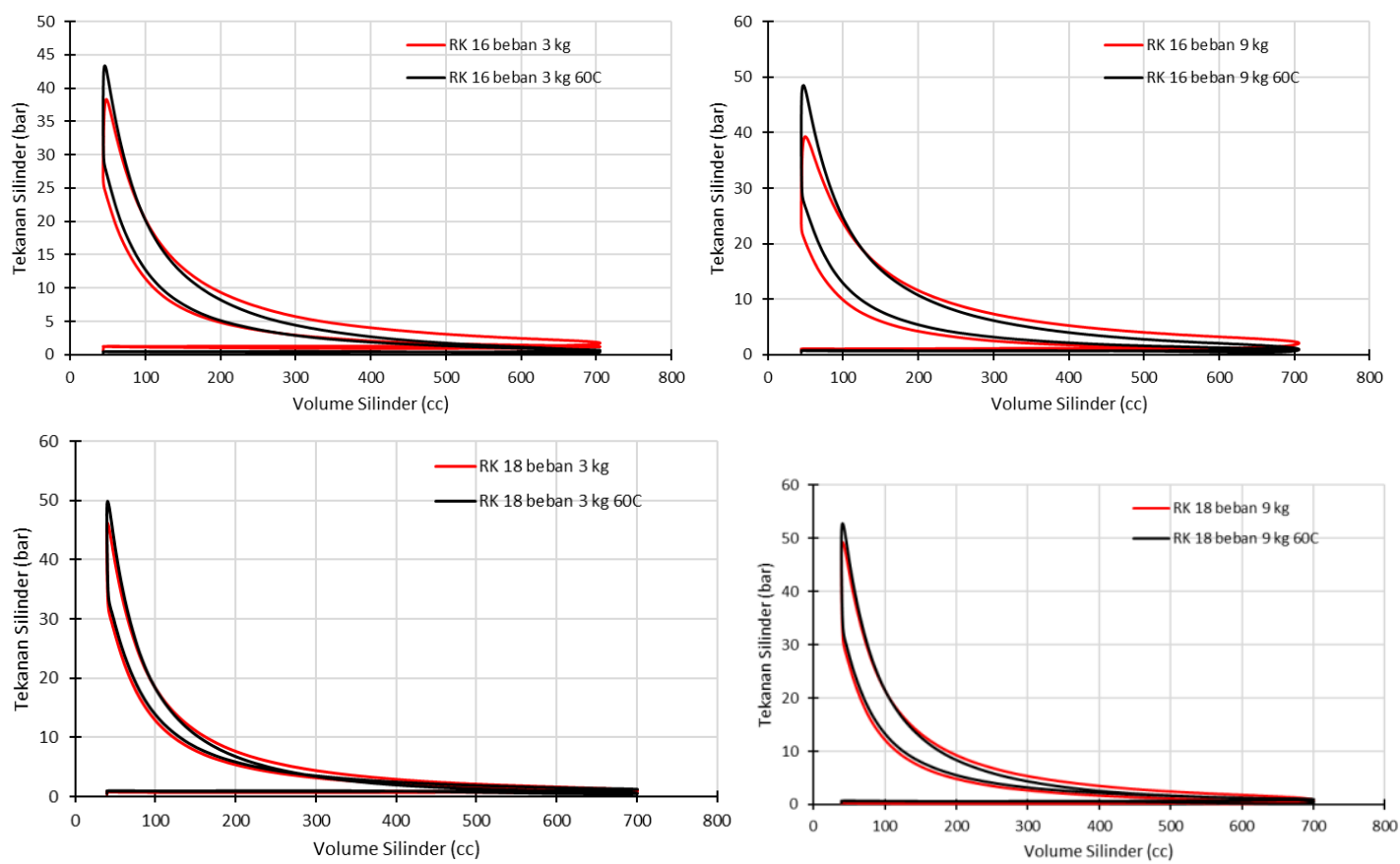

Gambar 4. Hubungan antara tekanan silinder dengan volume silinder

Gambar 4 memperlihatkan nilai tekanan dan volume silinder saat proses pembakaran. Semakin tinggi rasio kompresi maka semakin tinggi nilai tekanan silinder. Sedangkan tekanan maksimum pada pemanasan $60{ }^{\circ} \mathrm{C}$ juga cenderung lebih tinggi dibandingkan dengan biosolar tanpa pemanasan.
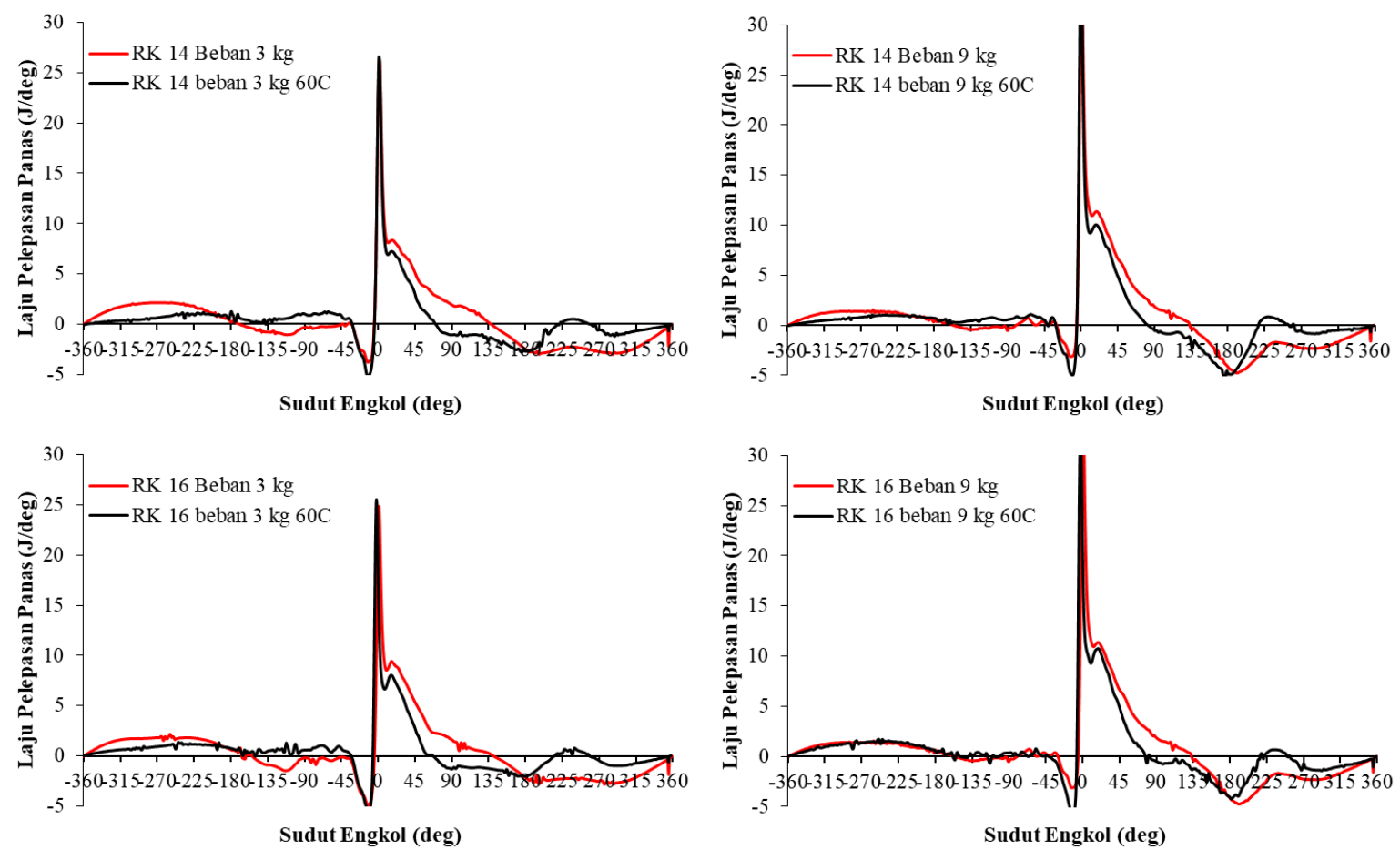

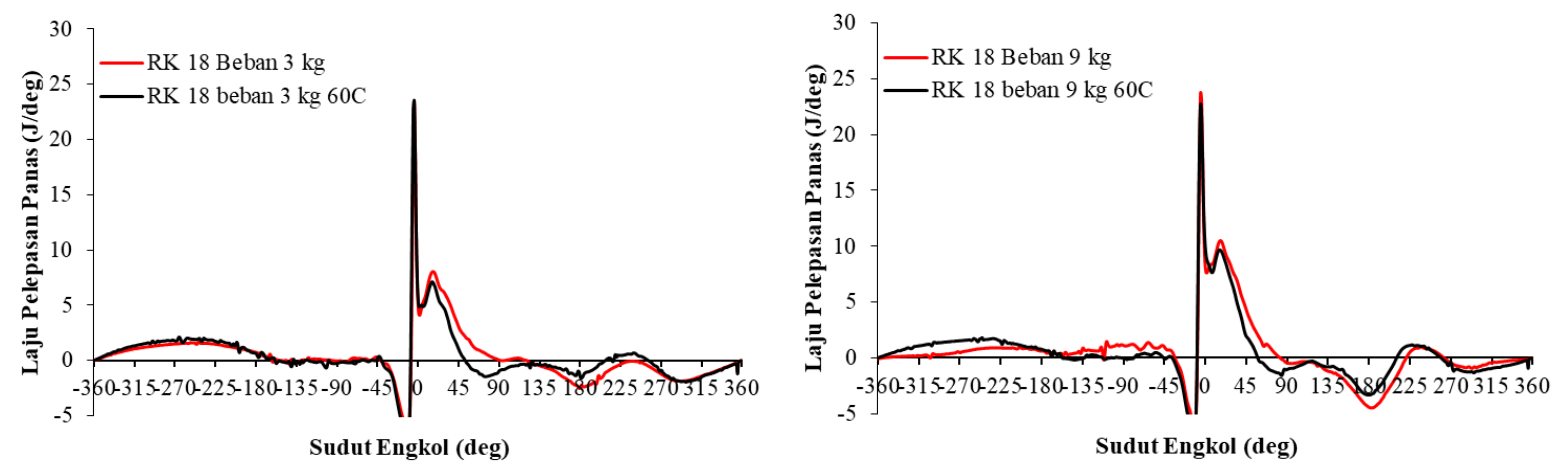

Gambar 5. Pelepasan Panas

Pada gambar 5 menunjukkan pelepasan panas terhadap sudut engkol yang digunakan untuk menganalisis fenomema pembakaran dalam silinder [14]. Perubahan rasio kompresi nampaknya mempengaruhi tingkat pelepasan panas, dimana semakin tinggi rasio kompresi semakin rendah nilai puncak pelepasan panas. Gambar 5 juga memperlihatkan bahwa pelepasan panas (net heat release) pada pemanasan $60^{\circ} \mathrm{C}$ memiliki nilai yang lebih rendah dari pelepasan panas (net heat release) pada tanpa pemanasan.

\section{KESIMPULAN}

Kesimpulan dari hasil penelitian yang telah dilakukan sebagai berikut:

a. Pemanasan biosolar pada pemanasan $60{ }^{\circ} \mathrm{C}$ menyebabkan SFC dan daya indikasi lebih rendah dan efisiensi mekanik lebih tinggi dibandingkan biosolar tanpa pemanasan

b. Awal pembakaran $(\mathrm{SoC})$ dari biodiesel pada pemanasan $60{ }^{\circ} \mathrm{C}$ cenderung lebih lambat dengan proses pembakaran yang berlangsung lebih singkat.

c. Proses pemanasan biosolar pada temperatur $60{ }^{\circ} \mathrm{C}$ menyebabkan tekanan maksimum lebih tinggi dan menurunkan nilai pelepasan panas.

\section{DAFTAR PUSTAKA}

[1] Adiarso, et all, "Outlook energi Indonesia 2020", Pusat Pengkajian Industri Proses dan Energi, Badan Pengkajian dan Penerapan Teknologi.

[2] A. Saravanan, et all, "Performance and emission characteristics of variable compression ratio CI engine fueled with dual biodiesel blends of Rapeseed and Mahua," Fuel, vol. 263, pp 116751, 1 March 2020

[3] Peraturan Menteri Energi Dan Sumber Daya Mineral Republik Indonesia, Penyediaan Dan Pemanfaatan Bahan Bakar Nabati Jenis Biodiesel Dalam Kerangka Pembiayaan Oleh Badan Pengelola Dana Perkebunan Kelapa Sawit, No. 41 Tahun 2018, 2018.

[4] Badan Pusat Statistik, Statistik Kelapa Sawit Indonesia 2019.

[5] K. A. Zahan, M. Kano, "Biodiesel Production from Palm Oil, Its By-Products, and Mill Effluent: A Review," Energies, vol. 11, pp 2132, 2018.

[6] Keputusan Direktur Jenderal Minyak dan Gas Bumi, Standar dan mutu (spesifikasi) bahan bakar nabati (biofuel) jenis biodiesel sebagai bahan bakar lain yang dipasarkan di dalam negeri, No. 189 K/10/DJE/2019, 2019

[7] Peraturan Menteri Energi dan Sumber Daya Mineral (ESDM), Perubahan ketiga atas Peraturan Menteri ESDM nomor 32 tahun 2008 tentang Penyediaan, Pemanfaatan dan Tata Niaga Bahan Bakar Nabati (Biofuel) sebagai Bahan Bakar Lain, No. 12 tahun 2015, 2015. 
[8] N. Namliwan, T. Wongwuttanasatian, "Performance of Diesel Engine Using Diesel B3 Mixed with Crude Palm Oil," The Scientific World Journal, Vol. 2014, Article ID 531868, 2014.

[9] A. Ganjehkaviri, et all, "Performance Evaluation of Palm Oil-Based Biodiesel Combustion in an Oil Burner," Energies, vol. 9, 97, 2016.

[10] L. Razzaq, et all, "Modeling Viscosity and Density of Ethanol-DieselBiodiesel Ternary Blends for Sustainable Environment," Sustainability, Vol. 12, 518, 2020.

[11] T. F. Yusaf, B. F. Yousif, M. M. Elawad, "Crude palm oil fuel for diesel-engines: Experimental and ANN simulation approaches," Energy 36, pp 4871-4878, 2011.

[12] T. H. Lim, S. Bari, C. W. Yu, “ Using crude palm oil (CPO) as diesel engine fuel, AJSTD, Vol. 19 (2), pp $1-13,2002$

[13] R. Rahim, et all, "Influence of fuel temperature on diesel engine performance operating with biodiesel blend," Journal of Mechanical Engineering and Sciences, Vol. 2, pp. 226-236, June 2012.

[14] Semin, et all, "The Effect of Heating of B20 Fuel to Combustion Characteristic on the Diesel Engine Based on Experiment," International Journal of Marine Engineering Innovation and Research, Vol. 5 (1), pp 1 -9, Mar. 2020. 